\title{
Characteristics of the purified uteroglobin-like protein from rabbit lung
}

\author{
M. Beato and H. M. Beier* \\ Institut für Physiologische Chemie, Philipps-Universität Marburg, D-3550 Marburg, and \\ *Abteilung Anatomie, Medizinische Fakultät, Rhein.-Westf. Technische Hochschule Aachen, \\ D-5100 Aachen, West Germany
}

\begin{abstract}
Summary. A uteroglobin-like protein was prepared from lung extracts of female rabbits by absorption to immobilized anti-uteroglobin immunoglobulin and purified to homogeneity by gel filtration on Sephacryl S-200. The final preparation is indistinguishable from uteroglobin according to its behaviour in Ouchterlony doublediffusion, polyacrylamide gel electrophoresis under denaturing and non-denaturing conditions, ultraviolet spectrum, tryptic peptide analysis, and progesterone-binding properties. Progesterone binding to the lung protein exhibits an affinity similar to that observed with authentic uteroglobin and is equally enhanced by reduction of the protein with dithiothreitol. Competition experiments with non-radioactive steroids demonstrate a similar steroid-specificity for both proteins. Progesterone binding causes a perturbation in the ultraviolet absorbance of tyrosine residues of the lung protein similar to that observed with uteroglobin. These data suggest that the proteins prepared from both sources are biochemically identical.
\end{abstract}

\section{Introduction}

The uterine secretion of the rabbit exhibits a typical protein pattern during early pregnancy. Between Days 3 and 8 post coitum a prominent protein band is seen in polyacrylamide gels which accounts for up to $40-50 \%$ of the total protein content of the uterine flushings. Since this protein was originally demonstrated in the pregnant and pseudopregnant uterus, it was called uteroglobin (Beier, 1966). Its postulated role in blastocyst development led Krishnan \& Daniel (1967) to propose the name 'blastokinin', but this designation awaits confirmation of the suggested function. Recent studies with refined immunological techniques have demonstrated the presence of uteroglobin-like antigens in other organs of the rabbit, e.g. the oviduct, the male genital tract, the digestive tract, and the respiratory tract (Kay \& Feigelson, 1972; Petzoldt, Dames, Gottschewski \& Neuhoff, 1972; Goswami \& Feigelson, 1974; Beier, Bohn \& Müller, 1975; Kirchner, 1976; Noske \& Feigelson, 1976; Daniel \& Milazzo, 1976; Kirchner \& Schroer, 1976; Bullock, 1977; Beier, 1977).

Uteroglobin has been purified to homogeneity and shown to consist of two identical polypeptide chains of 70 amino acids each, held together by two disulphide bonds and non-covalent interactions (Nieto, Ponstingl \& Beato, 1977). Endometrial uteroglobin can be induced by progesterone administration, which leads to an accumulation of the mRNA for a precursor of the uteroglobin monomer in the endometrial polysomes (Beier, 1968; Beier, Petry \& Kühnel, 1970; Arthur \& Daniel, 1972; Bullock \& Willen, 1974; Mayol \& Longenecker, 1974; Beato \& Arnemann, 1975; Beato \& Rungger, 1975; Bullock et al., 1976; Levey \& Daniel, 1976). In the oviduct, the uteroglobinlike protein is induced by oestrogens (Kay \& Feigelson, 1972; Goswami \& Feigelson, 1974), and in the lung its presence appears to be independent of ovarian steroids (Noske \& Feigelson, 1976). It seems relevant, therefore, to ask whether the uteroglobin-like antigen present in the lung is identical to uteroglobin in structure and function. The only established activity of uteroglobin is its ability to bind progesterone and other progestational steroids (Urzua, Stambaugh, Flickinger \& Mastroianni, 1970; Arthur, Cowan \& Daniel, 1972; Beato \& Baier, 1975; Beato, 1976; Fridlansky \& Milgrom, 
1976; Beato, Arnemann \& Voss, 1977). In this paper we present a procedure for the purification of the uteroglobin-like antigen from rabbit lung, so that it can be compared biochemically with uteroglobin.

\section{Materials and Methods}

$\left[{ }^{3} \mathrm{H}\right]$ Progesterone (sp. act. $101 \mathrm{Ci} / \mathrm{mmol}$ ) was obtained from Amersham-Buchler, Braunschweig, G.F.R. Dextran 500, Sephacryl S-200 and CNBr-activated Sepharose 4B were purchased from Pharmacia, Uppsala, Sweden. Org 2058 (16 $\alpha$-ethyl-21-hydroxy-19-norpregn-4-ene-3,20-dione) was a gift of Organon, Oss, Holland. R 5020 (17 $\alpha, 21$-dimethyl-19-norpregn-4,9-diene-3,20-dione) was provided by Roussell-UCLAF, Romainville, France.

Authentic uteroglobin was purified to homogeneity by the procedure described by Nieto et al. (1977). The uteroglobin-like antigen of the lung was isolated by absorption to anti-uteroglobin immunoglobulins coupled to Sepharose 4B. An anti-uteroglobin serum was prepared in sheep and in the goat as previously described (Beier et al., 1975) and the immunoglobulins were isolated by chromatography on DEAE-cellulose (Bohn, Schmidtberger \& Zilg, 1976). The purified immunoglobulin from $300 \mathrm{ml}$ serum was coupled to $\mathrm{CNBr}$-activated Sepharose $4 \mathrm{~B}$ by the procedure of Bohn et al. (1976) and the column was washed with buffer $\mathrm{A}(0 \cdot 1 \mathrm{M}-\mathrm{Tris}-\mathrm{HCl}, \mathrm{pH} 8 \cdot 0$, containing $1 \mathrm{M}-\mathrm{NaCl}$ and $0.1 \% \mathrm{~N}_{3} \mathrm{Na}$ ) before application of the lung extract. The preparation of the extract was as follows. Lungs from 12 intact female rabbits (total weight $260 \mathrm{~g}$ ) were minced, mixed with $260 \mathrm{ml}$ $0.9 \%(\mathrm{w} / \mathrm{v}) \mathrm{NaCl}$ and homogenized in an Ultra-Turrax. After centrifugation at $19000 \mathrm{~g}$ and $4^{\circ} \mathrm{C}$ for $30 \mathrm{~min}$, the supernatant was dialysed for $24 \mathrm{~h}$ against 10 litres buffer A. On each run, $50 \mathrm{ml}$ lung extract were applied to an $83-\mathrm{ml}$ column of the immunoabsorbent, and the column was extensively washed with buffer $\mathrm{A}$. The absorbed protein was eluted with $150 \mathrm{ml} 0.5 \mathrm{M}$-glycine- $\mathrm{HCl}$ buffer, $\mathrm{pH} 2 \cdot 5$, neutralized with $1 \mathrm{M}-\mathrm{NaOH}$ and concentrated by ultrafiltration through a UM-2 membrane (Amicon, Oosterhout, Holland). Further purification of the uteroglobin-like antigen was carried out as described in 'Results'.

Ouchterlony double diffusion was carried out on plates in $2.0 \%$ agarose, as described elsewhere (Beier et al., 1975).

Table 1. Effect of various steroids on the binding of $\left[{ }^{3} \mathrm{H}\right]$ progesterone to the lung protein and to uteroglobin

\begin{tabular}{|c|c|c|}
\hline \multirow[b]{2}{*}{ Competing steroid } & \multicolumn{2}{|c|}{$\left[{ }^{3} \mathrm{H}\right]$ Progesterone bound (c.p.m./50 $\mu \mathrm{l}$ ) } \\
\hline & Lung protein & Uteroglobin \\
\hline None & $12400(100 \%)$ & $13100(100 \%)$ \\
\hline Progesterone & $1948(15.7 \%)$ & $2895(22.1 \%)$ \\
\hline $5 \alpha$-Pregnan-3,20-dione & $1252(10.1 \%)$ & $1664(12.7 \%)$ \\
\hline Pregn-4-ene-3,20-dione & $7217(58.2 \%)$ & $8174(62 \cdot 4 \%)$ \\
\hline $17 \alpha$-Acetoxy-norethynodrel & $1848(14.9 \%)$ & $2410(18.4 \%)$ \\
\hline Org 2058 & $8618(69.5 \%)$ & $9340(71 \cdot 3 \%)$ \\
\hline R 5020 & $5357(43 \cdot 3 \%)$ & $5934(45 \cdot 3 \%)$ \\
\hline Pregnenolone & $9722(78.4 \%)$ & $10781(82.3 \%)$ \\
\hline Testosterone & $10763(86.8 \%)$ & $11869(90.6 \%)$ \\
\hline Oestradiol-17 $\beta$ & $10627(85.7 \%)$ & $12052(92.0 \%)$ \\
\hline Cortisol & $12412(100 \cdot 1 \%)$ & $13362(102.0 \%)$ \\
\hline
\end{tabular}

The binding of $\left[{ }^{3} \mathrm{H}\right]$ progesterone (sp. act. $5 \mathrm{Ci} / \mathrm{mmol}$ ), final concentration $0.5 \mu \mathrm{M}$, to the purified lung protein or uteroglobin $(15 \mu \mathrm{g} / \mathrm{ml})$ was tested after reduction with $5 \mathrm{~mm}$-dithiothreitol in the presence of a 10-fold molar excess of the indicated non-radioactive steroids (Beato, 1976). The values represent the average of duplicate determinations. 
Polyacrylamide gel electrophoresis under non-denaturing conditions was performed in $7 \cdot 5 \%$ gels (Davies, 1964). Electrophoresis in the presence of $1 \%$ sodium dodecylsulphate and $8 \mathrm{M}$-urea was carried out in $12.5 \%$ gels prepared as described by Swank \& Munkres (1971). To each gel $20 \mu \mathrm{g}$ protein were applied. After the run the gels were stained with Coomassie brilliant blue, destained in $5 \%$ methanol $-7.5 \%$ acetic acid, and scanned at $600 \mathrm{~nm}$.

Spectrophotometric measurements were performed in a Beckman Acta CII double-beam spectrophotometer equipped with a thermoregulated cuvette holder. Matched split-compartment cells were used for differential spectra (Beato et al., 1977).

Digestion with trypsin was carried out after oxidation of the proteins with performic acid (Beato \& Nieto, 1976) and the peptides were analysed on thin-layer chromatography as described in the legend to Text-fig. 5 .

The $\left[{ }^{3} \mathrm{H}\right]$ progesterone binding assay was based on the absorption of free steroid to charcoalcoated Dextran, and was carried out as previously described (Beato, 1976) in the presence of $2 \mathrm{mg}$ ovalbumin (Serva, Heidelberg)/ml. The concentration of protein was determined by the procedure of Lowry, Rosebrough, Farr \& Randall (1951) with crystallized bovine serum albumin (Behringwerke, Marburg) as standard.

\section{Structural studies}

\section{Results}

Immunoabsorption of $50 \mathrm{ml}$ lung extract to anti-uteroglobin immunoglobulin yielded a protein fraction (5-6 mg) which was immunologically indistinguishable from endometrial uteroglobin (Text-fig. 1): there was a clear continuity between the precipitin lines obtained with uteroglobin and the lung extracts. In polyacrylamide electrophoresis, the lung fraction exhibited a main band coinciding with the position of uteroglobin, but was still contaminated with other proteins (Text-fig. 2a). In the presence of urea and dodecylsulphate the main band coincided with uteroglobin, before and after reduction and carboxymethylation (Text-fig. 2b). The contaminant proteins were of high molecular weight and, even after reduction and carboxymethylation, their polypeptide chains migrated more slowly than the main band.

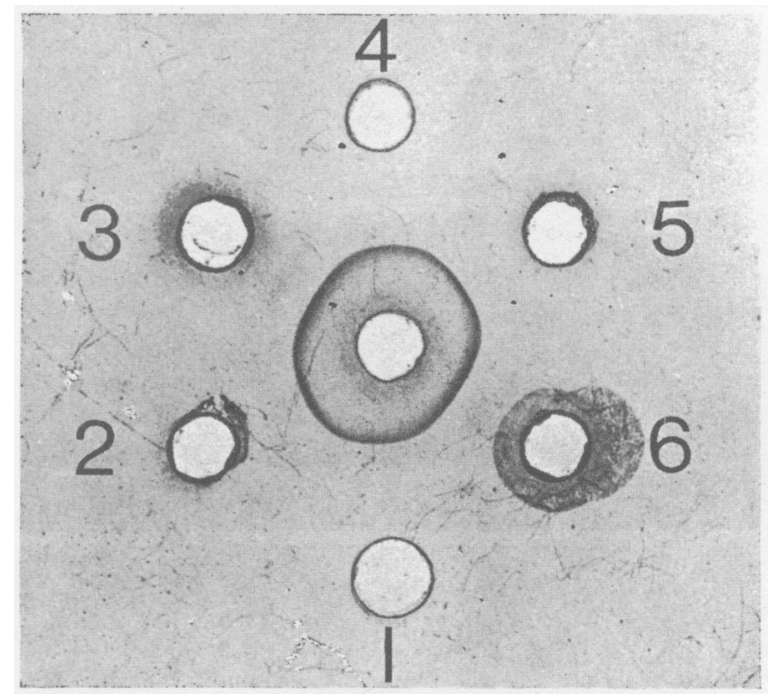

Text-fig. 1. Demonstration of the immunological identity of the lung extract protein and uteroglobin. The antiserum to uterine protein from the goat, containing mainly antibodies against uteroglobin and a few against albumin, was in the centre well of the Ouchterlony-agarose plate. The antigens were (1) uterine fluid from a rabbit at Day 6 p.c.; (2) rabbit lung tissue homogenate (1\% protein); (3) rabbit lung tissue homogenate $(4 \%$ protein); (4) uterine fluid from pseudopregnant rabbits after 4 days of progesterone treatment; (5) same as Well $2 ;(6)$ same as Well 3 . The precipitate of the immunodiffusion reactions is identical to the uteroglobin and the uteroglobin-like protein from the lung. 


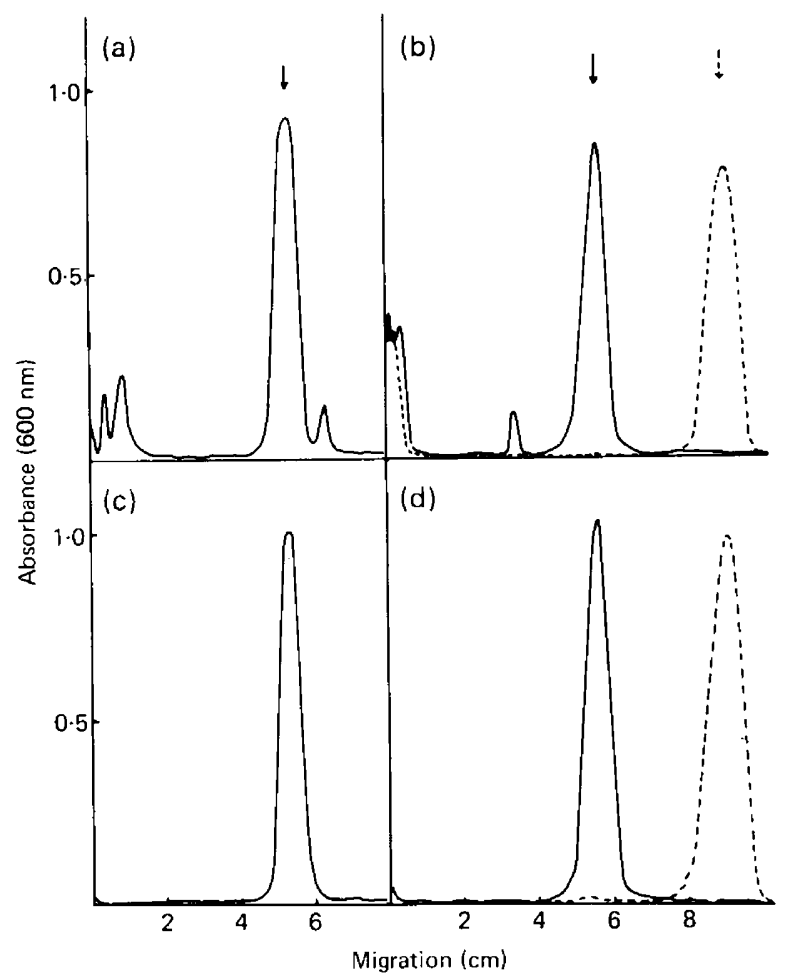

Text-fig. 2. Polyacrylamide gel electrophoresis of lung extract protein. Showing the absorbance at $600 \mathrm{~nm}$, as a function of electrophoretic migration, of (a) immunoabsorbed lung extract and (c) purified lung protein in non-denaturing gels, and (b) immunoabsorbed lung extract and (d) purified lung protein in gels containing urea and sodium dodecylsulphate. The arrows indicate the position of uteroglobin migration under these conditions. The continuous line represents the profiles obtained without reduction of the proteins and the broken lines give the profiles of the reduced and carboxymethylated proteins.

The elution profile of the immunoabsorbed lung extract from a column of Sephacryl S-200 is depicted in Text-fig. 3. There was a main peak of absorbance in the position of Fraction 34 which corresponds to an apparent molecular weight of 15000 and Stokes' radius of $18.5 \AA$ and coincides with the elution position of authentic uteroglobin (Beato $\&$ Baier, 1975). The high peak of absorbance in the low molecular weight region of the column corresponds to glycine which was present in the buffer used to elute the uteroglobin-like antigen from the immunoabsorbent (see above). The material eluted close to the void volume (high mol. wt.) corresponded to the minor contaminants observed in polyacrylamide gels. Gel electrophoresis of the $15000 \mathrm{~mol}$. wt peak (Fraction 34) showed that it was composed of a single protein band co-migrating with uteroglobin (Text-figs $2 \mathrm{c}$ and d). After reduction and carboxymethylation a single fast-moving band was observed in the same position as the uteroglobin monomer. These data demonstrate that like uteroglobin the lung protein is composed of two equal polypeptide chains held together by disulphide bonds (Nieto et al., 1977).

The ultraviolet absorbance spectrum of the purified lung protein (Text-fig. 4) was very similar to that of endometrial uteroglobin (Nieto et al., 1977). Before purification through Sephacryl S-200, the lung extract exhibited much higher molar absorbance in the region of aromatic amino acids, and a clear shoulder at $295 \mathrm{~nm}$, suggesting the presence of tryptophan. After final purification, however, the ultraviolet spectrum was typical of that of a protein lacking tryptophan and containing tyrosine and phenylalanine, as is the case for uteroglobin (Nieto et al., 1977).

The peptide pattern obtained after oxidation and tryptic digestion of the uterine and lung proteins shows a marked similarity (Text-fig. 5). The very minor differences may reflect the fact that the lung 
protein was not chromatographed on CM-cellulose (Nieto et al., 1977). Similar peptide patterns for both proteins were also observed in thin-layer plates developed without pyridine (data not shown).

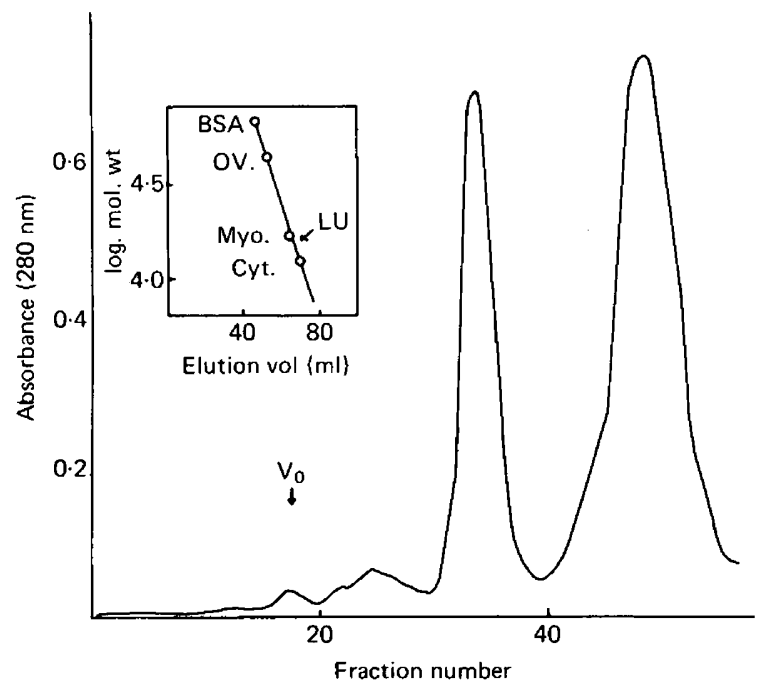

Text-fig. 3. Purification of the uteroglobin-like protein from lung extract by chromatography on Sephacryl S-200. An aliquot (5 mg protein) of the concentrated extract of rabbit lung in $1 \mathrm{ml} 0.5 \mathrm{M}-\mathrm{glycine}-\mathrm{HCl}$ buffer was applied to a column $(1.2 \times 85 \mathrm{~cm})$ of Sephacryl S-200 equilibrated with 10 mM-phosphate buffer, pH $7 \cdot 5$, containing $0 \cdot 15 \mathrm{M}-\mathrm{NaCl}$. The column was eluted with the same buffer at a flow rate of $15 \mathrm{ml} / \mathrm{h}, 2-\mathrm{ml}$ fractions were collected, and the absorbance of the eluate at $280 \mathrm{~nm}$ is shown. The inset represents a plot of the logarithm of the molecular weight of the protein standards (BSA, bovine serum albumin; OV., ovalbumin; Myo., myoglobin; Cyt., cytochrome C) against the corresponding elution volume. $\mathrm{LU}=$ the position where the uteroglobin-like antigen elutes from the column (between fractions 30 and 40 ); $\mathrm{Vo}=$ the excluded volume of the column.

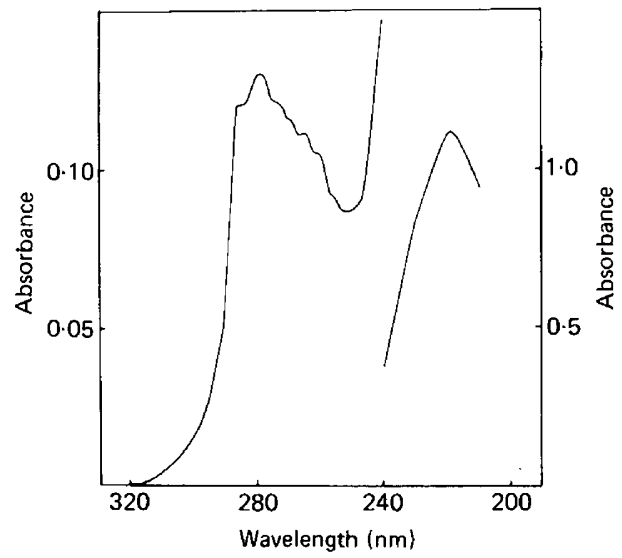

Text-fig. 4. Ultraviolet absorbance spectrum of the purified uteroglobin-like protein of the lung; $1 \mathrm{mg}$ purified lung protein/ml was dissolved in $10 \mathrm{~mm}$-phosphate buffer, $\mathrm{pH} 7 \cdot 5$, containing $0.15 \mathrm{M}-\mathrm{NaCl}$, and scanned against the solvent at $5 \mathrm{~nm} / \mathrm{min}$ by using $1 \mathrm{~cm}$ cuvettes and a bandwidth of $1 \mathrm{~nm}$ at $280 \mathrm{~nm}$. The scale on the right of the figure corresponds to the absorbance at wavelengths below $240 \mathrm{~nm}$. The values have been corrected for light scattering by extrapolation of the absorbance observed between 360 and $320 \mathrm{~nm}$ (Beaven \& Holiday, 1952). 


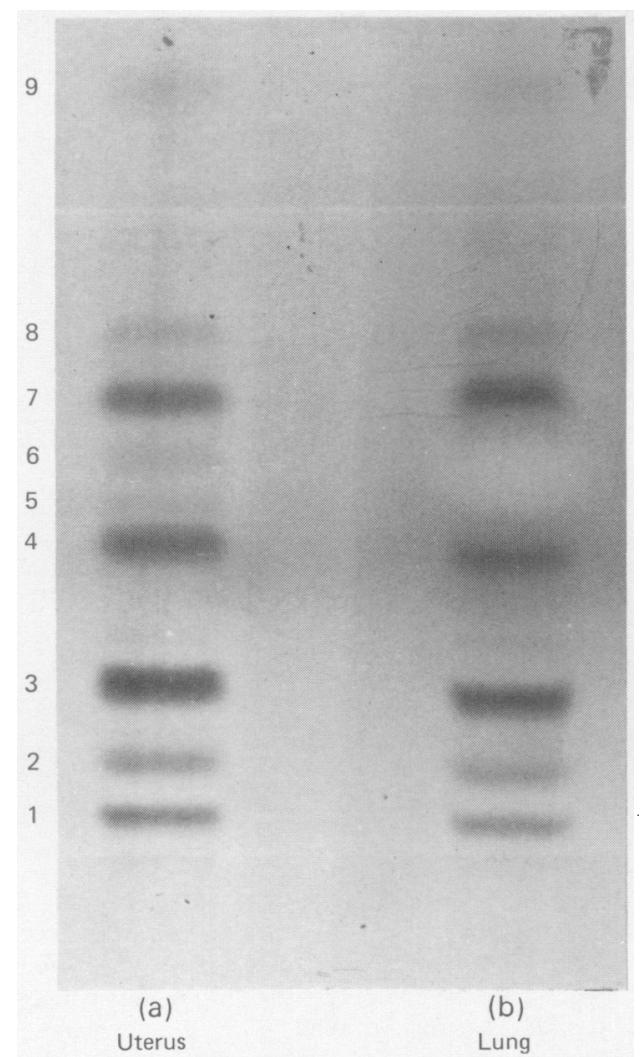

Text-fig. 5. Tryptic peptides of (a) uterine uteroglobin and (b) the uteroglobin-like protein of the lung. Purified uterine uteroglobin and the uteroglobin-like protein of the lung were oxidized with performic acid and digested with trypsin as previously described (Beato \& Nieto, 1976). The resulting peptides $(100 \mu \mathrm{g})$ were applied to precoated cellulose thin-layer plates $(20 \times 20 \mathrm{~cm}, 0.25 \mathrm{~mm}$ thick $)$ and chromatographed in butanol :acetic acid : pyridine $: \mathrm{H}_{2} \mathrm{O}(90: 18: 60: 72$ by vol.). The plates were dried, sprayed with ninhydrin reagent (E. Merck, Darmstadt) and dried at $70^{\circ} \mathrm{C}$ for $10 \mathrm{~min}$. The lung uteroglobin-like protein (b) exhibits a bright solvent spot which makes it difficult to recognize peptides 5 and 6 .

\section{Progesterone-binding activity}

The data above suggest that the purified lung protein is structurally identical to uteroglobin. To investigate their functional similarity, the progesterone-binding activity of the two proteins was investigated. The saturation of the binding sites obtained with increasing concentrations of $\left[{ }^{3} \mathrm{H}\right]$ progesterone was very similar for both proteins, and the calculated affinities at $4^{\circ} \mathrm{C}$ were $0.87( \pm 0 \cdot 11$ s.e.m.) $\times 10^{6} \mathrm{M}^{-1}$ for the lung protein, and $0.74( \pm 0.18) \times 10^{6} \mathrm{M}^{-1}$ for endometrial uteroglobin (Text-fig. 6). Assuming a molecular weight of 16000 (Nieto et al., 1977), the number of steroid binding sites per molecule of protein was $0.53( \pm 0.19)$ for the lung protein and $0.49( \pm 0.21)$ for uteroglobin. These data were obtained with proteins which were reduced with $5 \mathrm{~mm}$-dithiothreitol at $37^{\circ} \mathrm{C}$ for $15 \mathrm{~min}$ before the binding assay. If the reduction was omitted, the binding of $\left[{ }^{3} \mathrm{H}\right]$ progesterone to the lung protein was diminished by $70 \%$, exactly as has been described for uteroglobin (Beato \& Baier, 1975; Beato et al., 1977).

The influence of various non-radioactive steroids on the binding of $\left[{ }^{3} \mathrm{H}\right]$ progesterone to the two proteins was investigated. $5 \alpha$-Pregnandione and Norethynodrel were better competitors than progesterone for the binding of $\left[{ }^{3} \mathrm{H}\right]$ progesterone to uteroglobin (Beato, 1976), and they competed very efficiently for its binding to the lung protein. The synthetic progestins, Org 2058 and R 5020, which are excellent targets for the progesterone receptor (Philibert \& Raynaud, 1974; Fleischmann 
\& Beato, 1978), pregnenolone, testosterone and oestradiol-17 $\beta$ bound to both proteins with similar affinities. Cortisol did not affect the binding to either protein. A linear regression analysis of the data (Text-fig. 7) yielded a straight line with a correlation coefficient, $r^{2}$, of 0.99 , indicating very similar steroid specificity for the lung protein and uteroglobin.

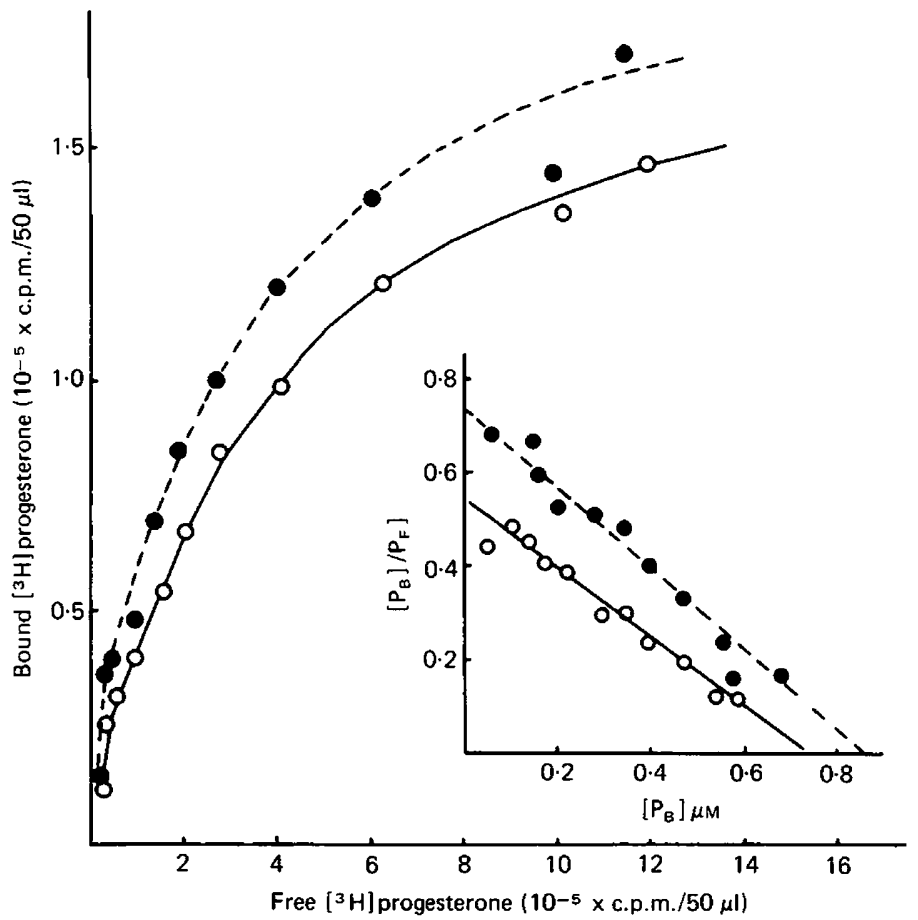

Text-fig. 6. Binding of $\left[{ }^{3} \mathrm{H}\right]$ progesterone to endometrial uteroglobin $(\mathrm{O})$ and to the uteroglobin-like protein of the lung (⿶). Purified endometrial uteroglobin $(24 \mu \mathrm{g} / \mathrm{ml})$ and the uteroglobin-like protein of the lung $\left(25 \mu \mathrm{g} / \mathrm{ml}\right.$ ) were incubated at $4^{\circ} \mathrm{C}$ for $2 \mathrm{~h}$ with increasing concentrations of $\left[{ }^{3} \mathrm{H}\right]$ progesterone in the presence of ovalbumin $(2 \mathrm{mg} / \mathrm{ml})$. The values represent the average of two determinations performed in duplicate. The inset shows a representation of the data by Scatchard (1949) plot analysis: $\left[P_{B}\right]$ and $\left[P_{F}\right]$ are the concentrations of bound and free progesterone, respectively.

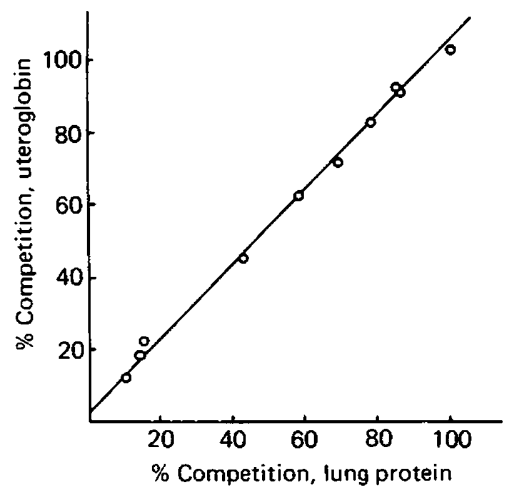

Text-fig. 7. Linear regression analysis of the steroid competition data. The data in Table 1 are represented graphically. The function was $y=3.92+0.995 x$ and the correlation coefficient was $r^{2}=0.995$. 
The interaction of progesterone with uteroglobin can be followed spectrophotometrically because of the 'quenching' of the ultraviolet absorbance of the 4-ene-3-keto structure of the steroid (Beato et al., 1977). A similar quenching of the progesterone spectrum was observed during binding to the purified lung protein (Text-fig. 8). The deflection was maximal around $260 \mathrm{~nm}$ and of the same magnitude as that observed with uteroglobin. Treatment with dithiothreitol (Text-fig. 8) showed that a reduction of the disulphide bonds was required for optimal binding to occur. The difference spectrum also showed the characteristic perturbance of the tyrosine chromophore, with positive deflections at 281 and $287 \mathrm{~nm}$, which has been detected for the binding of progesterone to uteroglobin (Beato et al., 1977). This finding suggests a similarity in the structure of the steroid-binding sites of the lung protein and uteroglobin and provides further evidence for the biochemical identity of both proteins.

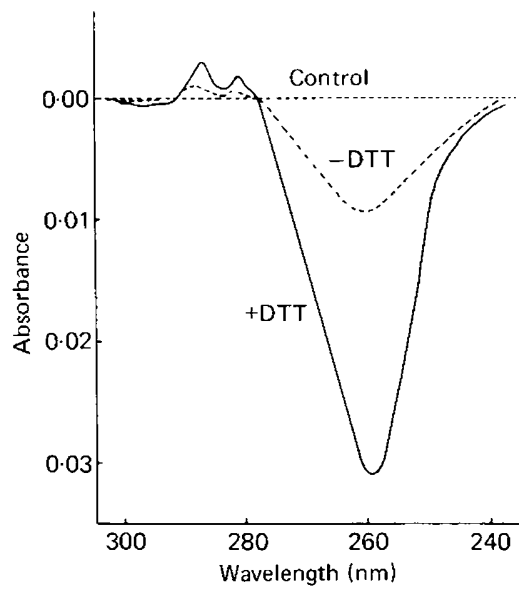

\begin{abstract}
Text-fig. 8. Difference spectrum of progesterone bound to the uteroglobin-like protein of the lung and the free components. Purified lung uteroglobin-like protein $(50 \mu \mathrm{M})$ was placed in one compartment of each split-compartment cell and the other side was filled with an equal volume $(1 \mathrm{ml})$ of a $20 \mu \mathrm{M}$-progesterone solution in $10 \mathrm{~mm}$-phosphate buffer, $\mathrm{pH} 7.5$, containing $0.15 \mathrm{M}-\mathrm{NaCl}$. Before mixing, a spectrum was run at $22^{\circ} \mathrm{C}$ and is indicated by the 'Control' line. The sample cuvette was then thoroughly mixed and after 10 min a new spectrum was recorded $(-\cdots)$. A similar experiment was carried out after addition of $5 \mathrm{~mm}$-dithiothreitol (DTT) to the protein side of the cells (-). The starting bandwidth was $1 \mathrm{~nm}$ at $280 \mathrm{~nm}$.
\end{abstract}

\title{
Discussion
}

The data presented in this paper strongly suggest that the lung tissue of oestrous rabbits contains a protein similar to uteroglobin. The presence in the lung extract of a protein antigenically related to uteroglobin has already been reported (Noske \& Feigelson, 1976; Daniel \& Milazzo, 1976; Beier, 1977; Bullock, 1977). Noske \& Feigelson (1976) have also shown that the lung protein behaves similarly to uteroglobin upon gel filtration on Sephadex G-100 and electrophoresis on polyacrylamide gels. The present results confirm the similarities in Stokes' radius and electrophoretic mobility of the lung protein and uteroglobin and show that the lung protein has characteristics of structure, composition, progesterone-binding activity and steroid specificity which are identical to those of uteroglobin. The ultraviolet spectrum of the lung protein, purified to apparent homogeneity, is very similar to that of uteroglobin, and indicates the presence of tyrosine and phenylalanine and the absence of tryptophan (Nieto et al., 1977).

Although a final demonstration of the identity of both proteins awaits sequence analysis, we consider that the biochemical similarities presented here justify the designation of the lung protein as uteroglobin-like. Although we have not performed a systematic quantitative study, the uteroglobin-like protein of the lung is by no means a minor contaminant of the lung extract. Between 1 
and $2 \mathrm{mg}$ uteroglobin were obtained from the lungs of one intact female rabbit. This finding, in conjunction with the presence of uteroglobin in the lung of ovariectomized rabbits (Noske \& Feigelson, 1976; Beier, Kirchner \& Mootz, 1978), which do not have uteroglobin in their genital tract secretions, makes the explanation improbable that the lung protein originates in the uterus and accumulates in the lung after being transported through the blood serum. In addition, even during early pregnancy very little, if any, uteroglobin has been demonstrated in the serum (Beier, 1968; Mayol \& Longenecker, 1974; Noske \& Feigelson, 1976). Bullock (1977) has reported the presence of an mRNA in the lung coding for the uteroglobin precursor, similar to that found in endometrium. If we therefore assume that the uteroglobin-like protein is synthesized in the lung, the question arises as to the regulation of its synthesis. Whereas in the endometrium uteroglobin is induced by progesterone, in the oviduct by oestrogens and in the male genital tract probably by androgens (for a review see Beato, 1977), the synthesis of uteroglobin in the lung appears to be independent of the hormonal status of male or female animals (Noske \& Feigelson, 1976) and the protein is already present in the fetal lung (Daniel \& Milazzo, 1976). The independence of lung 'uteroglobin' synthesis from gonadal hormones might simply reflect the absence of the corresponding hormone receptor, but the mechanism of the differential regulation of uteroglobin biosynthesis in various tissues offers interesting possibilities for the study of gene expression in eukaryotes. Finally, the presence of uteroglobin-like proteins with progesterone-binding activity in organs other than the uterus requires reconsideration of the function of uteroglobin and the significance of its interaction with steroids in the uterine secretion before implantation.

This work was supported by grants from the Deutsche Forschungsgemeinschaft (SFB 103, B-1, and SPP "Physiology and Pathology of Reproduction" Be 524/5). The expert technical assistance of Miss Jutta Arnemann, Mrs Maria Petuelli and Miss Sabine Hembeck is gratefully acknowledged. We thank Schering AG for kindly providing the steroids used in these studies.

\section{References}

Arthur, A.T. \& Daniel, J.C. (1972) Progesterone regulation of blastokinin production and maintenance of rabbit blastocysts transferred into uteri of castrated recipients. Fert. Steril. 23, 115-122.

Arthur, A.T., Cowan, B.D. \& Daniel, J.C. (1972) Steroid binding to blastokinin. Fert. Steril. 23, 85-92.

BeAto, M. (1976) Binding of steroids to uteroglobin. J. Steroid Biochem. 7, 327-334.

Beato, M. (1977) Hormonal control of uteroglobin biosynthesis. In Development in Mammals, Vol. I, pp. 361-384. Ed. M. H. Johnson. North-Holland, Amsterdam.

Beato, M. \& Arnemann, J. (1975) Hormone-dependent synthesis and secretion of uteroglobin in isolated rabbit uterus. FEBS Letters 58, 126-129.

BeAto, M. \& BAIER, R. (1975) Binding of progesterone to the proteins of the uterine luminal fluid. Identification of uteroglobin as the binding protein. Biochim. biophys. Acta 392, 346-356.

BeATo, M. \& Nieto, A. (1976) Translation of the mRNA for rabbit uteroglobin in cell-free systems. Evidence for a precursor protein. Eur. J. Biochem. 64, 15-21.

Beato, M. \& Rungger, D. (1975) Translation of the messenger RNA for rabbit uteroglobin in Xenopus oocytes. FEBS Letters 59, 305-309.

Beato, M., Arnemann, J. \& Voss, H.-J. (1977) Spectrophotometric study of progesterone binding to uteroglobin. J. Steroid Biochem. 8, 725-730.
Beaven, G.H. \& Holiday, E.R. (1952) Ultraviolet absorption spectra of proteins and amino acids. Adv. Protein Chem. 7, 319-386.

Beier, H.M. (1966) Das Proteinmilieu im Serum, Uterus und Blastocysten des Kaninchens vor der Nidation. In Biochemie der Morphogenese. Chairman W. Beermann. Symp. of the Deutsche Forschungsgemeinschaft, Konstanz.

BeIER, H.M. (1968) Uteroglobin: a hormone sensitive endometrial protein involved in blastocyst development. Biochim. biophys. Acta 160, 289-291.

BeIER, H.M. (1977) Immunologische und biochemische Analysen am Uteroglobin und dem Uteroglobinähnlichen Antigen der Lunge. Medsche Welt 28 (N.F.), 788-792.

Beier, H.M., Petry, G. \& Kühnel, W. (1970) Endometrial secretion and early mammalian development. In Mammalian Reproduction, pp. 264-285. Eds H. Gibian \& E. J. Plotz. Springer, Berlin.

BeIER, H.M., BohN, H. \& Müller, W. (1975) Uteroglobin-like antigen in the male genital tract secretions. Cell Tiss. Res. 165, 1-11.

Beier, H.M., Kirchner, C. \& Mootz, U. (1978) Uteroglobin-like antigen in the pulmonary epithelium and secretion of the lung. Cell Tiss. Res. (in press).

Bohn, H., Schmidtberger, R. \& Zilg, H. (1976) Isolierung des schwangeschaftsspezifischen $\beta_{1}$ - 
Glycoproteins $\left(\mathrm{SP}_{1}\right)$ antigenverwandter Proteine durch Immunabsorption. Blut 32, 103-113.

Bullock, D.W. (1977) Progesterone induction of mRNA and protein synthesis in the rabbit uterus. Ann. N.Y. Acad. Sci. 286, 260-272.

Bullock, D.W. \& WilleN, G.F. (1974) Regulation of a specific uterine protein by estrogen and progesterone in ovariectomized rabbits. Proc. Soc. exp. Biol. Med. 146, 294-298.

Bullock, D.W., Woo, S.L.C. \& O'Malley, B.W. (1976) Uteroglobin mRNA: translation in vitro. Biol. Reprod. 15, 435-443.

Daniel, J.C. \& Milazzo, Y.T. (1976) Continuity of a rabbit antigen between generations. Cancer Res. 36, 3409-3411.

Davis, B.Y. (1964) Disc electrophoresis. II. Material and application to human serum proteins. Ann. N.Y. Acad. Sci. 121, 404-413.

FleischmanN, G. \& Beato, M. (1978) Characterization of the progesterone receptor of rabbit uterus with the synthetic progestin 16a-ethyl-21-hydroxy-19-norpregn-4-ene-3,20-dione. Biochim. biophys. Acta (in press).

Fridlansky, F. \& Milgrom, E. (1976) Interaction of uteroglobin with progesterone, $5 \alpha$-pregnane-3,20dione and estrogens. Endocrinology 99, 1244-1251.

Goswami, A. \& Feigelson, M. (1974) Differential regulation of a low-molecular weight protein in oviductal and uterine fluids by ovarian hormones. Endocrinology 95, 669-675.

Kay, E. \& Feigelson, M. (1972) An estrogen modulated protein in rabbit oviductal fluid. Biochim. biophys. Acta 271, 436-441.

KIRCHNER, C. (1976) Uteroglobin in the rabbit. I. Intracellular localization in the oviduct, uterus and preimplantation blastocyst. Cell Tiss. Res. 170, 415-424.

Kirchner, C. \& SCHROER, H.G. (1976) Uterine secretion-like proteins in the seminal plasma of the rabbit. J. Reprod. Fert. 47, 325-330.
KrishnaN, R.S. \& Daniel, J.C. (1967) Blastokinin: inducer and regulator of blastocyst development in the rabbit uterus. Science, $N . Y .158,490$.

LEVEY, I.L. \& DANIEL, J.C. (1976) Isolation and translation of blastokinin mRNA. Biol. Reprod. 14, 163-174.

Lowry, O.H., Rosebrough, N.J., FarR, A.L. \& RANDALL, L.J. (1951) Protein measurement with the Folin phenol reagent. J. biol. Chem. 193, 265-275.

Mayol, R.F. \& Longenecker, D.E. (1974) Development of a radioimmunoassay for blastokinin. Endocrinology 95, 1534-1542.

Niero, A., Ponstingl, H. \& Beato, M. (1977) Purification and quaternary structure of the hormonally induced protein uteroglobin. Archs Biochem. Biophys, 180, 82-92.

Noske, I.G. \& Feigelson, M. (1976) Immunological evidence of uteroglobin (blastokinin) in the male reproductive tract and in nonreproductive ductal tissues and their secretions. Biol. Reprod. 15, 704-713.

Perzoldt, U., Dames, W., Gottschewski, G.H.M. \& Neuhoff, V. (1972) Das Proteinmuster in frühen Entwicklungsstadien des Kaninchens. Cytobiologie 5, 272-280.

Philibert, D. \& Raynaud, J.P. (1974) Progesterone binding in the immature rabbit and guinea pig uterus. Endocrinology 94, 627-632.

SCATChaRd, G. (1949) The attractions of proteins for small molecules and ions. Ann. N.Y. Acad. Sci. 51, 660-672.

Swank, R.T. \& Munkres, K.D. (1971) Molecular weight analysis of oligopeptides by electrophoresis in polyacrylamide gel with sodium dodecyl sulfate. Analyt. Biochem. 39, 462-477.

Urzua, M.A., Stambaugh, R., Flickinger, G. \& Mastroianni, L. (1970) Uterine and oviduct fluid protein patterns in the rabbit before and after ovulation. Fert. Steril. 21, 860-865.

Received 26 October 1977 